\title{
PALEOBIOGEOGRAPHY OF PSEUDOTEXTULARIA ELEGANS DURING THE LATEST MAASTRICHTIAN GLOBAL WARMING EVENT
}

\author{
Richard K. Olsson, ${ }^{1}$ James D. Wright, and Kenneth G. Miller \\ Department of Geological Sciences, Rutgers University, Piscataway, New Jersey 08854
}

ABSTRACT

A latest Maastrichtian global warming event, which began approximately $450 \mathrm{k.y}$. and ended about $22 \mathrm{k.y}$. prior to the $\mathrm{K} / \mathrm{T}$ boundary, is associated with the poleward migration of the warm-water planktonic foraminifer Pseudotextularia elegans. The warming event was apparently inititated by greenhouse warming due to the main outpouring of the Deccan Traps in India and is now well documented in the North and South Atlantic Oceans and in North America by the poleward migration of warm-water planktonic foraminifera and subtropical vegetation.

A cooling trend ca $22 \mathrm{kyr}$ prior to the $\mathrm{K} / \mathrm{T}$ boundary caused marine $\delta^{18} \mathrm{O}$ values to return to climatic conditions recorded prior to the onset of warming and thus does not represent a significant change in long-term climate. Planktonic foraminifera responded by migration to the latest Maastrichtian global warming and cooling before their mass extinction at the $\mathrm{K} / \mathrm{T}$.

\section{INTRODUCTION}

Planktonic foraminiferal studies by Troelsen (1955) and Wicker (1953) first noted the possibility of a late Maastrichtian shifting of water masses in the "Cretaceous Baltic Sea". Wicker (1953) was the first to draw attention to a cooling trend, indicated by the progressive southward retreat of Globotruncana in the Late Cretaceous of southern Sweden, northwestern Germany, and Poland. Also, according to Wicker, warmer waters returned in the late Maastrichtian with the appearance of Pseudotextularia elegans (Rzehak) in northwestern Germany, Denmark, and Sweden. He believed that this species was brought into this region by a warm current from the south. Troelsen (1955) pointed to the occurrence of Contusotruncana contusa (Cushman) in the upper Maastrichtian Kjölby Gaard Marl of the White Chalk of Denmark and concluded that, due to its absence in the ordinary chalk facies of Denmark and Sweden, it must be a southern species brought northward by an incursion of warm water. These early studies, although generalized, established the value of planktonic foraminifera as biogeographic tracers of water masses in the Cretaceous. In this study we show the importance of $P$. elegans as a tracer of water mass movement in the North and South Atlantic during the latest Maastrichtian.

\section{METHODS}

Clean specimens of the planktonic foraminifer Rugoglobigerina and the benthic foraminifer Anomalinoides midwayensis were picked from the $>125 \mu \mathrm{m}$ size fraction. Sta-

${ }^{1}$ E-mail: Olsson@rci.rutgers.edu ble isotope values of foraminifera were measured in stable isotope laboratories at the University of Maine and Rutgers University. The analyses from the University of Maine laboratory were made on a VG Prism II mass spectrometer using an IsoCarb automated carbonate preparation system. At Rutgers University, the measurements were made on a Micromass Optima mass spectrometer using a Multiprep automated carbonate preparation system. Samples were react-

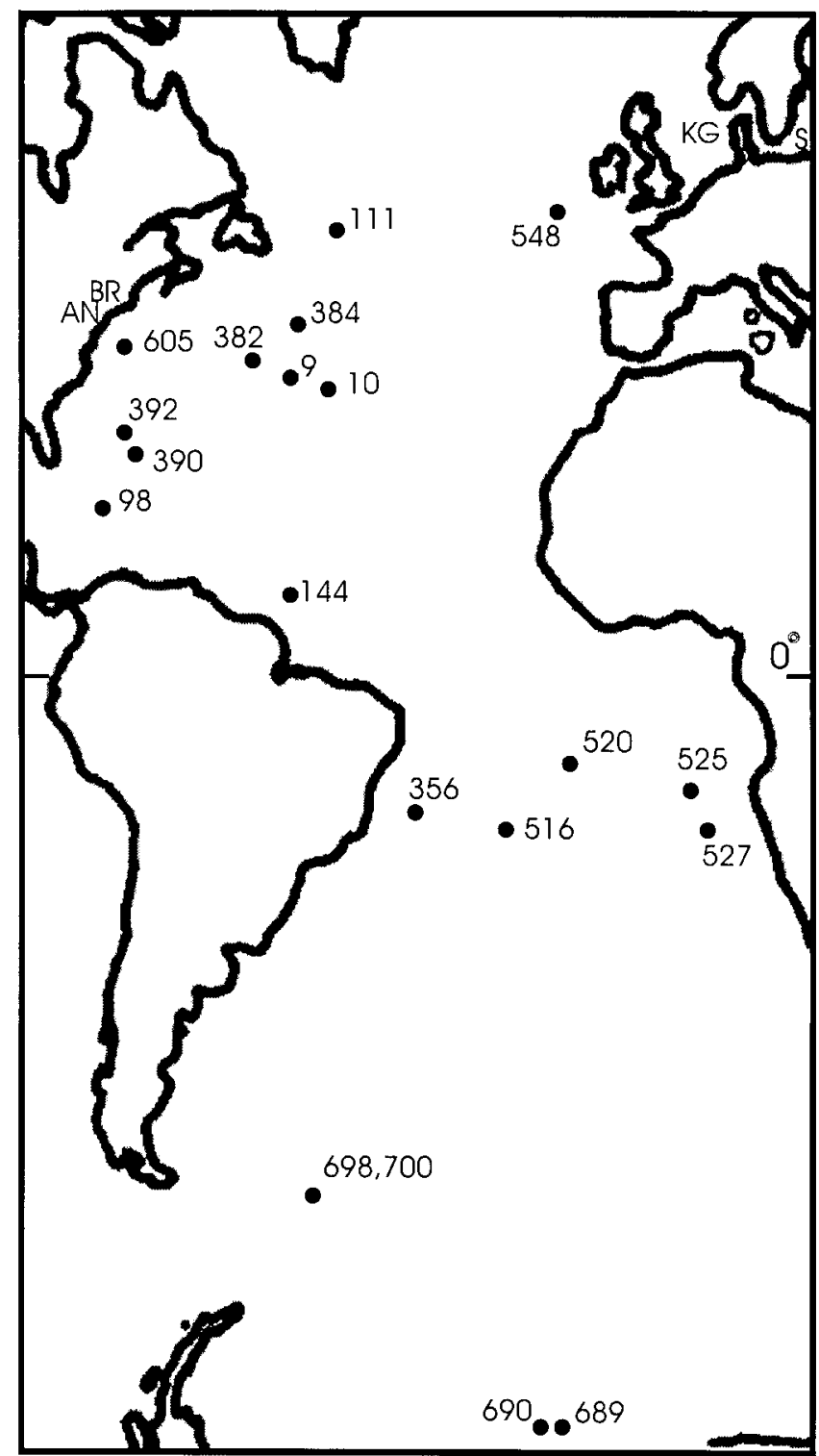

FIGURE 1. Location of the Ancora (AN), Bass River (BR) Boreholes (Ocean Drilling Program Leg 174AX), outcrop sections in Denmark $(\mathrm{KG}=$ Kjölby Gaard Marl) and Sweden $(\mathrm{S}=$ Maastrichtian White Chalk), and deep sea drill sites used in this study. 


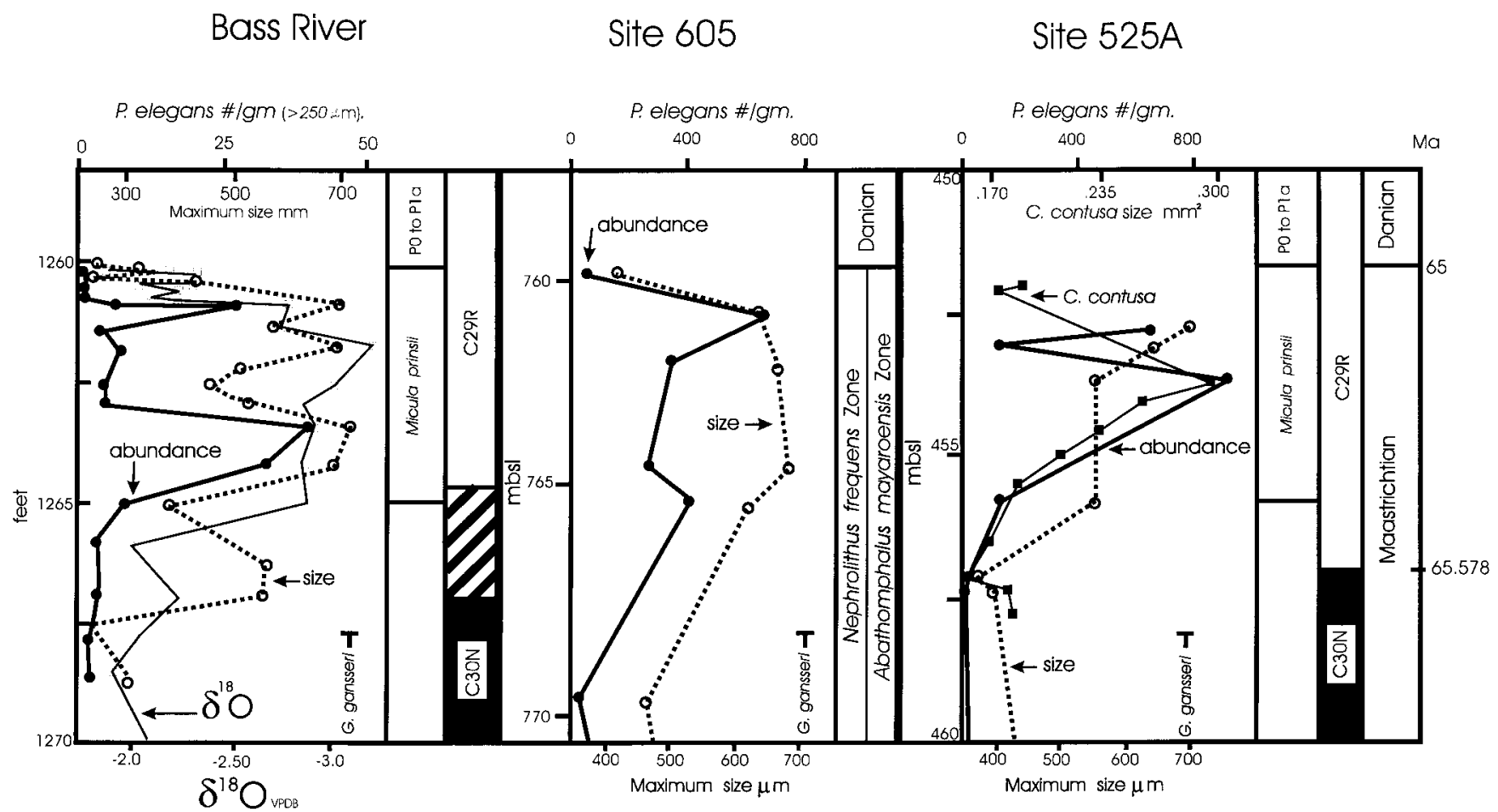

FIGURE 2. Comparision of abundance and size of Pseudotextularia elegans between Bass River Borehole and Deep Sea Drilling Sites 605 and 525. $\delta^{18} \mathrm{O}$ values for the planktonic foraminifer Rugoglobigerina are shown for Bass River, and size of Contusotruncana contusa (data from Kucera and Malmgren, 1998) is shown for Hole 525A. Abathomphalus mayaroensis and Nephrolithus frequens Zones identified at Site 605 by Jansen and Kroon (1987) and Lang and Wise (1987), respectively are shown. Although Lang and Wise did not identify Micula prinsii at Site 606, they placed the base of the $N$. frequens Zone between 765.5 and 779.4 mbsl. This suggests that the M. prinsii Subzone, (= upper part of the N. frequens Zone) would encompass the abundance and size peaks of P. elegans at Site 605.

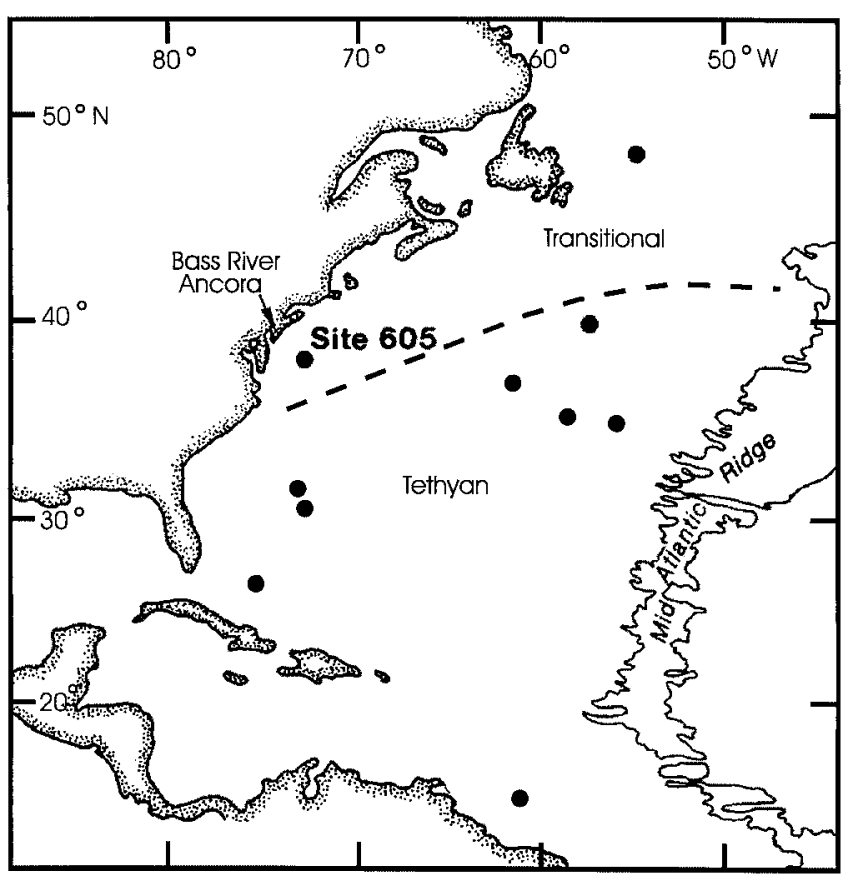

FIGURE 3. Boundary between late Maastrichtian Transitional and Tethyan water masses in the North Atlantic as interpreted by Nyong (1985) and Jansen and Kroon (1987). ed in $100 \%$ phosphoric at $90^{\circ} \mathrm{C}$. Oxygen isotopic values in Table 1 are reported relative to V-PDB by normalizing the NBS-19 or NBS-20 standards to the values reported in Coplen et al. (1983). The standard deviation $(1 \sigma)$ of the standard (a minimum of 6 standards were measured with each run of 30 samples) is $0.06 \%$ for $\delta^{18} \mathrm{O}$.

Pseudotextularia elegans is actually a minor component of late Maastrichtian warm Transitional and Tethyan planktonic foraminiferal assemblages but, nevertheless, it is a very important climatic indicator. Adult tests of Pseudotextularia elegans tests that are typical of warm Transitional and Tethyan waters are larger than $+250 \mu \mathrm{m}$ in maximum width and length so that a $+250 \mu \mathrm{m}$ size sieve (60 mesh) was used to separate each sample for ease of determining the abundance of this species. The total number of tests for each sample was counted in this size fraction. The smaller size fraction in each sample was also examined to determine if there was any significance number of small adult or neanic stage $P$. elegans in this fraction that might skew the results. The occurrence of identifiable P. elegans in the smaller size fraction was insignificant and in many cases the species was absent from this fraction. The total number of tests of $P$. elegans in samples varied between 0 and 450, with the greatest number recorded in the $\delta^{18} \mathrm{O}$ defined warm interval. At DSDP Sites 525A and 605 the total abundance of this species is expressed as the number of tests per gram of sample. Due to terrigenous sediment dilution in the middle shelf setting of the Bass River Borehole the total number of tests of $P$. elegans is expressed as the number of tests 


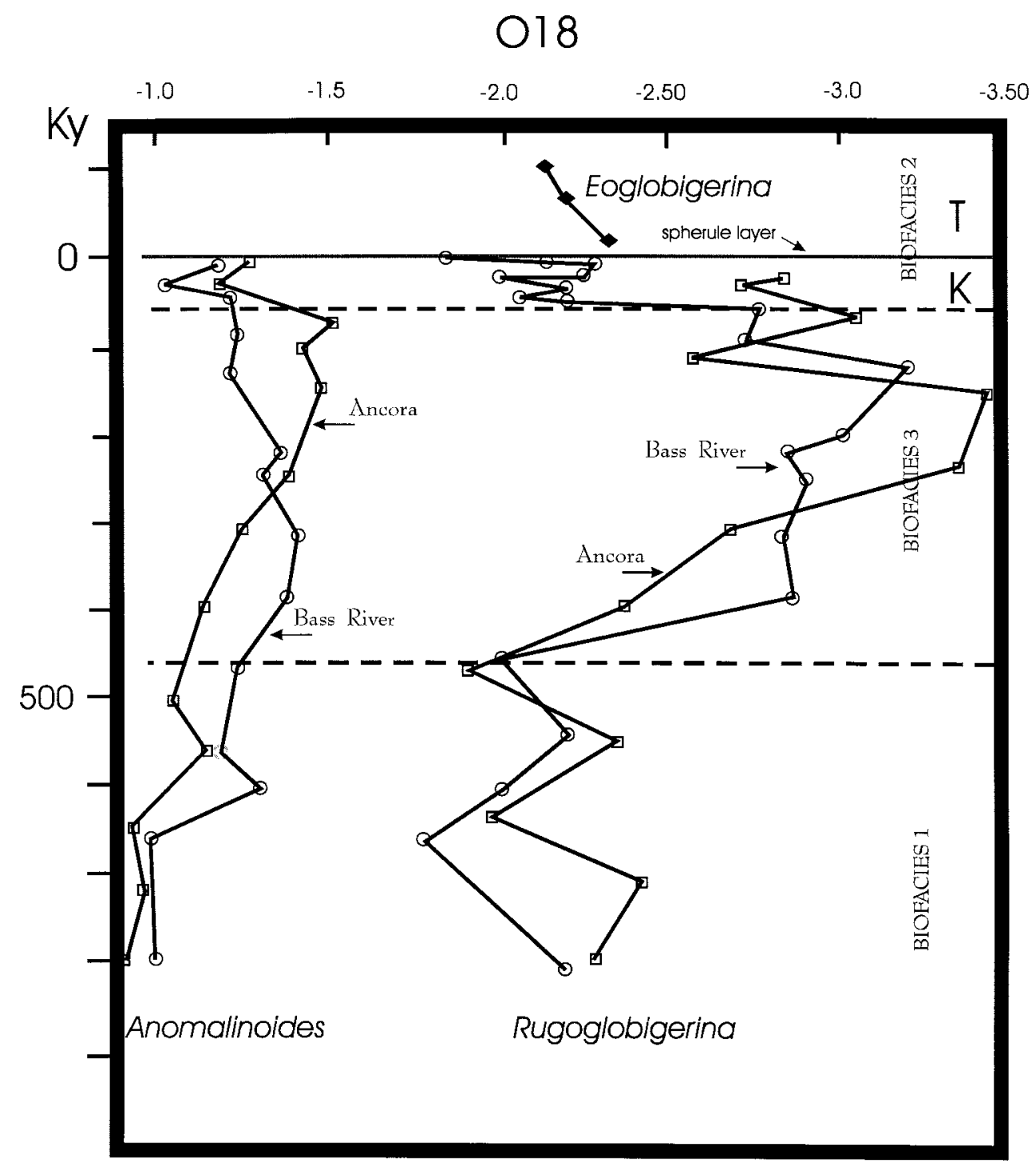

FIGURE 4. Oxygen isotope values for Anomalinoides and Rugoglobigerina in the uppermost Maastrichtian in the Ancora and Bass River Boreholes. Note sharp negative shift of $1-1.5 \%$ in $\delta^{81} \mathrm{O}$ values of Rugoglobigerina, indicating a significant warming of sea surface temperatures in the latest Maastrichtian. Biofacies 1, 2, 3 are benthic foraminifera biofacies identified in the Bass River Borehole (Olsson et al., 2001). Note that biofacies 3 correlates with the warming trend, suggesting that bottom waters were affected by the warming trend. See text for discussion of difference in $\delta^{18} \mathrm{O}$ values of Anomalinoides and Rugoglobigerina.

per gram of the $250 \mu \mathrm{m}$ size fraction in order to show more clearly trends in the abundance of tests. The total number of tests counted among samples at Bass River varied between 1 and 123 .

The maximum size of $P$. elegans was determined by measuring the length of the test, which is quickly and easily done by using an ocular micrometer during the counting procedure.

\section{PALEOBIOGEOGRAPHY OF PSEUDOTEXTULARIA ELEGANS}

Stratigraphic studies on the Maastrichtian white chalk of Sweden show that the first occurrence (FO) of Pseudotextularia elegans (low-mid latitude range: lower to upper Maastrichtian) is in the uppermost part of the chalk (Malmgren, 1982), suggesting a latest Maastrichtian poleward mi- gration of this species. A similar latest Maastrichtian poleward migration in the Austral Realm of Pseudotextularia elegans about 500 k.yr. before the K/T extinction event was documented by Huber $(1990,1992)$ and Huber and Watkins (1992). They linked the poleward migration of $P$. elegans in both hemispheres to a brief period (estimated at 200 to $300 \mathrm{kyr}$ ) of surface water warming that was detected by Stott and Kennett (1990) in the $\delta^{18} \mathrm{O}$ record at ODP Sites 689 and 690 on Maud Rise, Southern Ocean (Fig. 1). A paleobiogeographic study of the distribution of planktonic foraminifera within the calcareous nannofossil Micula prinsii Zone (uppermost Maastrichtian) at North and South Atlantic deep sea drill sites (Sites 356, 384, 516, 525, 527, 546) by Malmgren (1991) concluded that $P$. elegans characterized warm transitional waters (Fig. 1). A later study (Kucera and Malmgren, 1998) of the same South Atlantic 
TABle 1. Olsson, Wright, Miller

\begin{tabular}{|c|c|c|c|c|c|c|c|}
\hline \multicolumn{3}{|c|}{ Bass River } & \multicolumn{3}{|c|}{ Ancora } & \multirow[b]{2}{*}{$\underset{(\mathrm{ft})}{\text { Sample depth }}$} & \multirow[b]{2}{*}{$\begin{array}{c}\text { Eoglobigerina } \\
\quad \delta^{18} \mathrm{O}\end{array}$} \\
\hline $\begin{array}{l}\text { Sample depth } \\
\text { (ft) }\end{array}$ & $\begin{array}{c}\text { Anomalinoides } \\
\delta^{18} \mathrm{O}\end{array}$ & $\begin{array}{c}\text { Rugoglobigerina } \\
\delta^{18} \mathrm{O}\end{array}$ & $\begin{array}{l}\text { Sample depth } \\
\text { (ft) }\end{array}$ & $\begin{array}{c}\text { Anomalinoides } \\
\delta^{18} \mathrm{O}\end{array}$ & $\begin{array}{c}\text { Rugoglobigerina } \\
\delta^{18} \mathrm{O}\end{array}$ & & \\
\hline 1260.41 & -1.174 & & 618.40 & -1.28 & -2.92 & 1259.58 & -2.10 \\
\hline 1260.51 & -1.075 & & 618.50 & -1.21 & -2.82 & 1259.65 & -2.17 \\
\hline 1260.55 & -1.22 & -1.83 & 619.00 & -1.48 & -3.11 & 1259.68 & -2.29 \\
\hline 1260.62 & -1.16 & -2.11 & 619.50 & -1.45 & -2.67 & & \\
\hline 1260.68 & -1.18 & -2.3 & 620.00 & -1.47 & -3.46 & & \\
\hline 1260.77 & -1.181 & -2.23 & 621.00 & -1.38 & -3.37 & & \\
\hline 1260.85 & & -1.99 & 622.00 & -1.32 & -2.80 & & \\
\hline 1260.90 & & -2.16 & 623.00 & -1.15 & -2.52 & & \\
\hline 1260.91 & & -2.06 & 624.00 & -1.05 & -2.10 & & \\
\hline 1261.00 & -1.26 & -2.16 & 625.00 & -1.12 & -2.48 & & \\
\hline 1261.50 & -1.22 & -2.76 & 626.00 & -0.91 & -2.14 & & \\
\hline 1261.82 & & -2.65 & 627.00 & -0.94 & -2.54 & & \\
\hline 1262.00 & -1.212 & -3.22 & 628.00 & -0.89 & -2.42 & & \\
\hline 1262.50 & & -3.02 & & & & & \\
\hline 1263.00 & -1.347 & -2.88 & & & & & \\
\hline 1263.50 & -1.322 & -2.9 & & & & & \\
\hline 1264.00 & -1.416 & -2.87 & & & & & \\
\hline 1265.10 & -1.388 & -2.89 & & & & & \\
\hline 1266.00 & -1.212 & -1.98 & & & & & \\
\hline 1267.00 & -1.19 & -2.22 & & & & & \\
\hline 1268.00 & -1.309 & -1.99 & & & & & \\
\hline 1269.00 & -1.075 & -1.79 & & & & & \\
\hline 1271.00 & -1.08 & -2.18 & & & & & \\
\hline
\end{tabular}

sites (DSDP Sites 356, 516, 525, 527) demonstrated a latest Maastrichtian (upper part of the Micula prinsii Zone) poleward migration in the mid-latitude South Atlantic of Contusotruncana contusa low-latitude morphotypes. This migration event was correlated with a terminal Maastrichtian warming event between 65.3 and $65.2 \mathrm{Ma}$, based on a linear interpolation within paleomagnetic Subchron C29R. The poleward migration of $C$. contusa low-latitude morphotypes ended with their rapid withdrawal from the mid-latitude South Atlantic Ocean before the Cretaceous-Tertiary boundary. At Hole 525A, a rapid increase in the abundance and maximum size of $P$. elegans coincides with the appearance of $C$. contusa low-latitude morphotypes (Fig. 2), suggesting that these $P$. elegans morphotypes also migrated from a low-latitude region.

During the late Maastrichtian (Fig. 3), the New Jersey margin was situated near the boundary between North Atlantic Transitional and Tethyan faunal provinces (Nyong, 1985; Olsson and Wise, 1987). Jansen and Kroon (1987) also noted that warm-water and cold-water taxa were present in the Maastrichtian (Abathomphalus mayaroensis Zone) at DSDP Site 605 (paleodepth $2500 \mathrm{~m}$ ) on the New Jersey continental slope. They concluded that a clockwise circulation, similar to the modern North Atlantic pattern, brought warm-water taxa northward from the Tethyal bioprovince. This warming observed at the slope site is well expressed in two coastal plain boreholes.

In the Ancora and Bass River Boreholes in the coastal plain, the latest Maastrichtian warming trend is clearly defined in the $\delta^{18} \mathrm{O}$ record by a sharp decrease of $1-1.5 \%$ in shells of Rugoglobigerina near the base of Subchron C29R (Figs. 2, 4). If this signal is attributed solely to temperature change, then surface waters warmed by 4 to $7^{\circ} \mathrm{C}$. Other studies have estimated a $3-4^{\circ} \mathrm{C}$ global warming at this time (Barrerra and Savin, 1999). Regional precipitation may have been altered during the latest Cretaceous warming and part of the $\delta^{18} \mathrm{O}$ signal at Ancora and Bass River may reflect increased fresh-water influence (with low $\delta^{18} \mathrm{O}_{\text {water }}$ values). Nonetheless, it is clear that substantial surface-water warming occurred on the New Jersey shelf after 65.5 Ma, prior to the $\mathrm{K} / \mathrm{T}$ boundary.

Coeval benthic foraminiferal $\delta^{18} \mathrm{O}$ values at both Ancora and Bass River (Fig. 4) decreased by only $\sim 0.2-0.5 \%$, indicating only a $1-2^{\circ} \mathrm{C}$ warming of bottom waters in middleouter shelf environments. These shelf bottom waters can be used to approximate the upper thermocline water, indicating less of a warming in the upper thermocline. Before the warm excursion, the planktonic-benthic $\delta^{18} \mathrm{O}$ difference $\left(\Delta \delta^{18} \mathrm{O}\right)$ was on the order of $1 \%$. During peak warmth, $\Delta \delta^{18} \mathrm{O}$ values reached a maximum of $2 \%$. These data show a more pronounced warming in surface waters relative to the upper thermocline, a larger surface to bottom temperature difference, and an increase in the strength of the thermocline. Thus, it is clear not only that the waters on the NJ shelf became warmer, they also became more stratified during the latest Cretaceous.

Low $\delta^{18} \mathrm{O}$ values continued to near the top of the $M$. prinsii Subzone. We estimate that the warming lasted $\sim 428$ k.y. and ended $\sim 22 \mathrm{k} . \mathrm{y}$. prior to the K/T boundary. Interpolation between two broadly spaced datum levels (C29R/C30N and base of $M$. prinsii) does not provide age resolution better than $\pm 0.1 \mathrm{~m}$.y. or so. Thus, the age estimates provided here are tentative. Nevertheless, the constraints placed by magnetochronology and biostratigraphy are firm: the warming event began after $65.5 \mathrm{Ma}$ and ended immediately before ( $\sim 22$ k.y.) the K/T boundary. Coinciding with this warming period is an increase in the abundance and maximum size of P. elegans in the coastal plain sites (Fig. 5). Due to the shallow paleodepth of these locations at this time $(<100 \mathrm{~m})$ planktonic taxa are not as abundant as they are at the open 


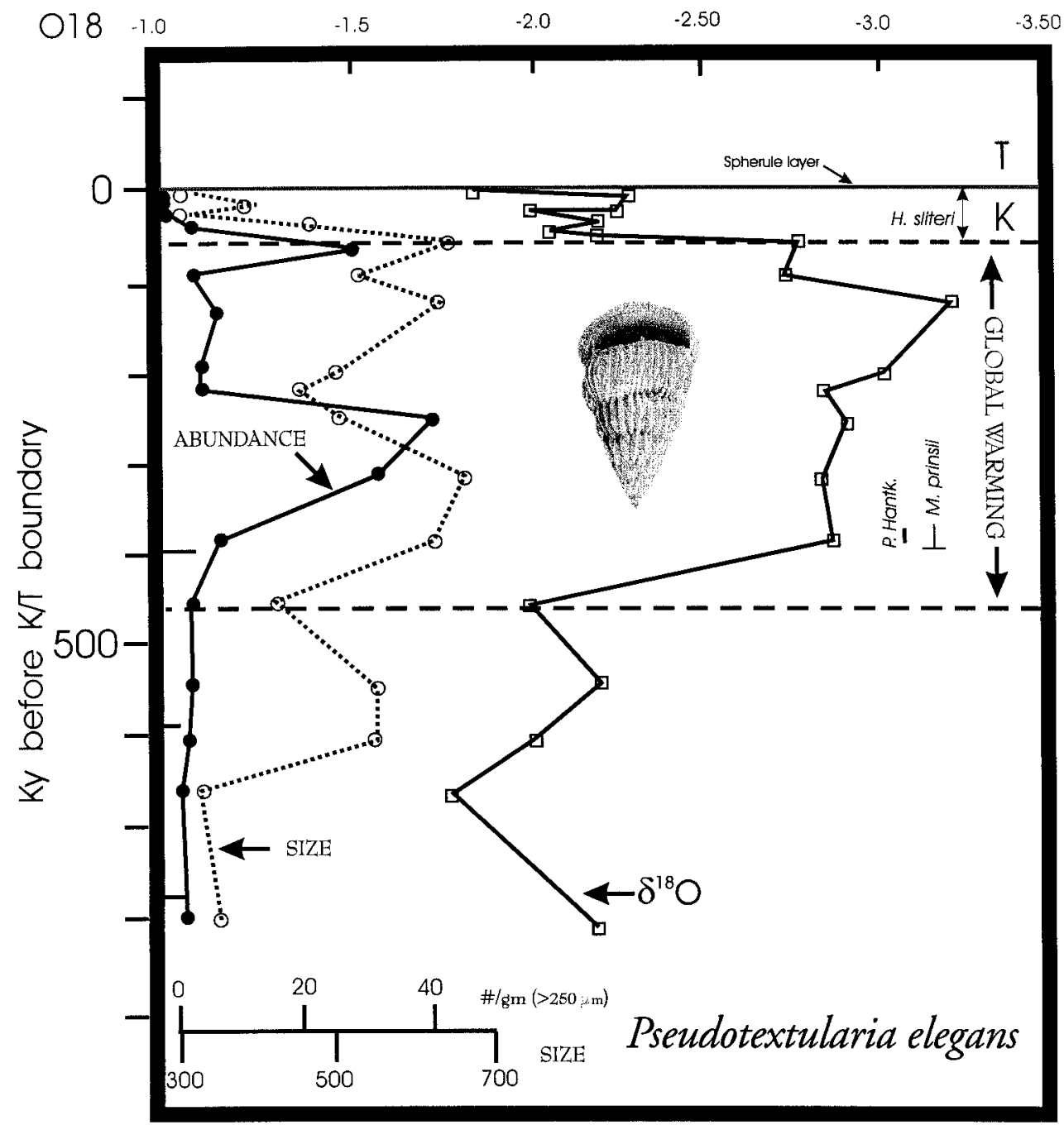

FIGURE 5. Comparison of the abundance and size of Pseudotextularia elegans with the $\delta^{18} \mathrm{O}$ values measured on Rugoglobigerina in the Bass River Borehole. A $\sim 5^{\circ} \mathrm{C}$ warming of sea surface temperatures is associated with an increase in abundance and size of Pseudotextularia elegans indicating that this species was adapted to the warm tethyan waters that had shifted into the New Jersey area. The occurrences of the planktonic foraminifers Hedbergella sliteri and Plummerita hantkeninoides are shown in the figure.

ocean deep sea drill sites. Nevertheless, the consistent occurrence of $P$. elegans with species such as Globotruncana aegyptiaca Nakkady and Pseudoguembelina costulata (Cushman) indicates the influence of warm Tethyan waters (Malmgren, 1991). In addition, Planoglobulina acervulinoides (Egger) and Racemiguembelina fructicosa (Egger), warm transitional species according to Malmgren (1991), first occur rarely in this interval. Very rare occurrences of Plummerita hantkeninoides Brönnimann, an uppermost Maastrichtian tropical Tethyan species, are observed at the beginning of the warming trend in the Bass River Borehole (Fig. 5). Thus, the $\delta^{18} \mathrm{O}$, abundance, and size data all indicate a latest Maastrichtian warming in the North Atlantic.

At Site 605 (paleodepth $2500 \mathrm{~m}$ ) on the New Jersey slope, a marked increase in abundance and size of $P$. elegans begins just above the highest occurrence (HO) of Gansserina gansseri (Bolli) (Fig. 2). At Bass River, the HO of $G$. gansseri occurs just below the warming trend. Site 605 is unsuitable for $\delta^{18} \mathrm{O}$ analysis due to diagenesis. Although dissolution has affected some parts of the uppermost
Maastrichtian section at Site 605 (Nederbragt, 1989), the marked increase in abundance and size of $P$. elegans occurs in an interval relatively unaffected by dissolution, indicating that the increase is not due to selective destruction of dissolution-prone species. In addition, Contusotruncana contusa has abundance and maximum size peaks parallel to those of $P$. elegans, indicating a poleward shifting of warm transitional and/or Tethyan waters in the North Atlantic.

\section{DISCUSSION}

Barrera and Savin (1999) concluded in their study of $\delta^{18} \mathrm{O}$ records that intermediate and deep waters in the South and North Atlantic, Indian, and Pacific Oceans warmed globally by $3-4^{\circ} \mathrm{C}$ between 65.5 and $65.3 \mathrm{Ma}$ and then cooled slightly about $65.2 \mathrm{Ma}$. They suggested that this increase in marine temperatures correlated with the main episode of Deccan Trap eruptions which may have led to greenhouse global warming. Li and Keller (1998) identified a latest Maastrichtian (Chron C29R) warming trend in $\delta^{18} \mathrm{O}$ values of benthic 


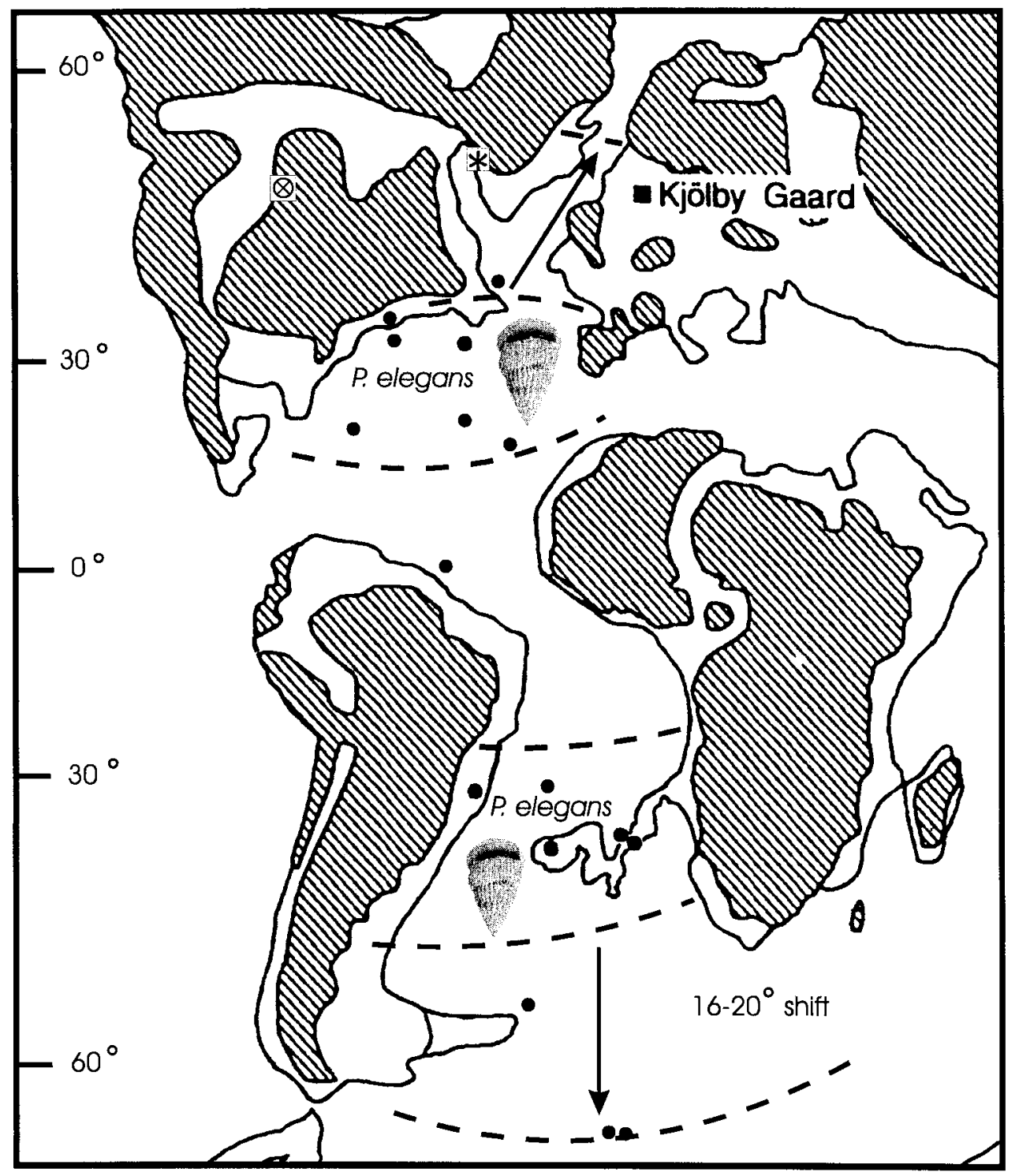

$\otimes$ Hell Creek subtropical flora

* West Greenland megathermal flora $>20^{\circ} \mathrm{C}$

- DSDP \& ODP sites used in this study

Figure 6. Paleogeographic map of the Maastrichtian North and South Atlantic showing the habitat of Pseudotextularia elegans. A 16-20 latitudinal poleward shift of this species is interpreted to have occurred during the latest Maastrichtian global warming trend. Dots are locations of deep sea drill sites used in this reconstruction. Also shown are the locations of the Hell Creek subtropical flora and the West Greenland megathermal flora.

foraminifera at ODP Site 525, but due to lack of a clear warming trend in $\delta^{18} \mathrm{O}$ values of planktonic foraminifera in this interval, they ruled out a link to the Deccan Traps volcanism. Our analysis of North and South Atlantic deep sea drilling sites indicates that a poleward shift of populations of Pseudotextularia elegans of 16-20 degrees latitude occurred during this latest Maastrichtian warming trend (Fig. 6). Olsson et al. (2001) suggested that the warming trend observed at Bass River was due to an increase in greenhouse gases initiated by the main outpouring of the Deccan Traps in India, which started near the base of Subchron C29R
(Courtillot et al., 1986; Hansen, et al., 1996). At Bass River, Olsson et al. (2001) recorded a positive shift in ${ }^{87} \mathrm{Sr} /{ }^{86} \mathrm{Sr}$ ratios near the base of Subchron C29R that clearly correlates with the latest Maastrichtian warming trend. High-resolution (50 k.y.-scale) Maastrichtian variations in ${ }^{87} \mathrm{Sr} /{ }^{86} \mathrm{Sr}$ observed at Bass River showed a remarkably similar pattern to coeval sections at Bidart, France and El Kef, Tunisia (Vonhof and Smit, 1997). The variations include a sharp decrease in Chron C29r that can be ascribed to increased weathering of basaltic rocks associated with the Deccan Traps (Vonhof and Smit, 1997). 


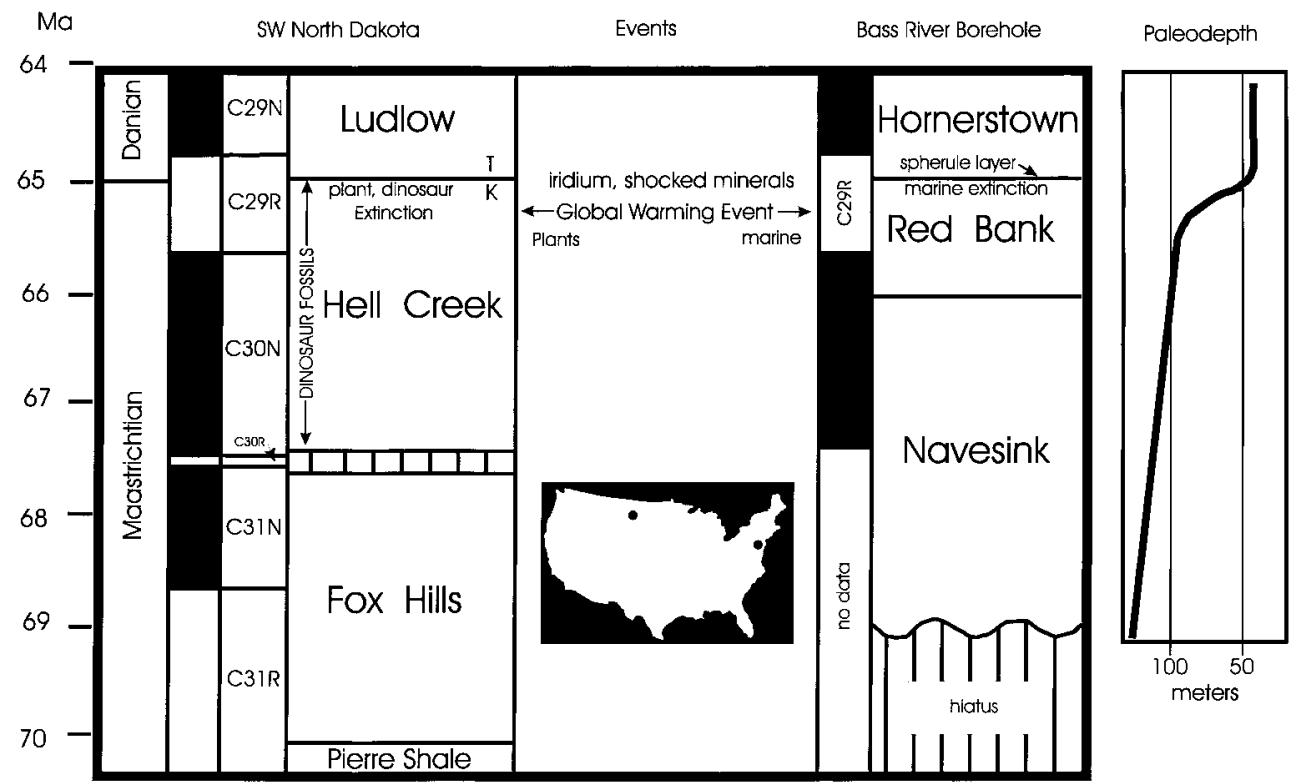

FIGURE 7. Correlation of marine and nonmarine K/T boundary sections at Bass River and southwest North Dakota.

Significant climate warming during the latest Maastrichtian is indicated by the megaflora in the upper part of the Hell Creek Formation, South Dakota (Johnson, 1999) (Fig. 6). A diverse, subtropical flora as characterized by leaf physiognomy appears near the beginning of Subchron C29R. Latest Maastrichtian warm climate may also be reflected in the flora of the Lower Atanekerdluk of West Greenland (Fig. 6). Although the Lower Atanekerdluk is not precisely dated, other than being older than late Danian, Wolfe and Upchurch (1987) suggest that the flora could represent a late Maastrichtian warm interval. They further suggest that the strong floristic similarity of the Lower Atanekerdluk with Late Cretaceous floras of southeastern North America indicates that its flora represents a megathermal climate. A significant warming of North Atlantic waters around Greenland, as is indicated by the late Maastrichtian shift in populations of $P$. elegans and the $\delta^{18} \mathrm{O}$ record, is consistent with their contention.

Oxygen isotope values at Bass River returned to values recorded prior to the onset of warming at about $65.02 \mathrm{Ma}$ (Figs. 4, 5). Barrera and Savin (1999) also noted a slight cooling in their latest Maastrichtian $\delta^{18} \mathrm{O}$ records. Kucera and Malmgren (1998) recorded a rapid withdrawal of lowlatitude $C$. contusa morphotypes from the mid-latitude South Atlantic Ocean following the end of the warming trend. This cooling following the Maastrichtian warm event thus appears to be global in extent.

The latest Maastrichtian warming trend appears not to have greatly affected planktonic foraminiferal assemblages, which simply migrated with the shifting of water masses. However, the first occurrence (FO) of Plummerita hantkeninoides appears to be associated with the onset of warming as does the FO of the calcareous nannofossil Micula prinsii (Fig. 5). Towards the end of the warming event at Bass River Hedbergella sliteri Huber, a high-latitude middle to upper Maastrichtian Austral species (Huber, 1992, 1994), appears and ranges to the top of the Maastrichtian (Fig. 5). This first known northern hemisphere presence of $H$. sliteri shows that $H$. sliteri achieved a bipolar distribution in the latest Maastrichtian, which is important to understanding late Maastrichtian ocean climate and the dispersal of planktonic foraminifera.

\section{CONCLUSIONS}

The latest Maastrichtian global warming event began approximately $450 \mathrm{k} . \mathrm{y}$. and ended about $22 \mathrm{k} . \mathrm{y}$. prior to the $\mathrm{K} / \mathrm{T}$ boundary. It apparently was initiated by greenhouse warming due to the main outpouring of the Deccan Traps in India. The warming event is now well documented in the North and South Atlantic Oceans and in North America by the poleward migration of warm-water planktonic foraminifera and subtropical vegetation. Correlation of this event within Subchron C29R in marine and nonmarine stratigraphic sections (Fig. 7) provides a framework for assessing the end Cretaceous extinctions of marine and nonmarine biota. Plant, dinosaur, and marine extinctions coincide with the $\mathrm{K} / \mathrm{T}$ boundary ca $22 \mathrm{kyr}$ after the climate shifted to cooler conditions. Cooling is associated with a longer term lowering of sea level prior to K/T boundary time (Fig. 7). However, the cooling trend caused marine $\delta^{18} \mathrm{O}$ values to return to climatic conditions recorded prior to the onset of warming (Barrera and Savin, 1999; this paper), and thus does not represent a significant change in long-term climate. Planktonic foraminifera respondend by migration to the latest Maastrichtian global warming and cooling before their mass extinction at the $\mathrm{K} / \mathrm{T}$.

\section{ACKNOWLEDGMENTS}

Drilling of the Ancora and Bass River Boreholes was supported by National Science Foundation grant NSF EAR97-08664 and the N. J. Geological Survey. Cores were obtained by the N. J. Coastal Plain Drilling Project supported by the Continental Dynamics and Ocean Drilling Programs. We thank B. T. Huber and B. J. Malmgren for reviews. 


\section{REFERENCES}

Barrera, E., and SAvin, S. M., 1999, Evolution of late CampanianMaastrichtian marine climates and oceans, in Barrera, E., and Johnson, E., eds., Evolution of the Cretaceous ocean-climate system: Geological Society of America Special Paper 332, p. 245282.

Coplen, T. B., Kendall, C., and Hopple, J., 1983, Comparison of stable isotope reference sections: Nature, v. 302, p. 236-238.

Courtillot, V., Besse, J., Vandamme, D., Montigny, R., Jaeger, J-J., and CAPPETTA, H., 1986, Deccan flood basalts at the Cretaceous/Tertiary boundary?: Earth and Planetary Science Letters, v. 80 , p. $361-374$

Hansen, H. J., Toft, P., Mohabey, D. M., and Surkar, A., 1996, Lameta age: Dating the main pulse of the Deccan Traps volcanism, in National Symposium Deccan Flood Basalts, India: Gondwana Geology Magazine, v. 2, p. 365-374.

Huber, B. T., 1990, Maestrichtian planktonic foraminifer biostratigraphy of the Maud Rise (Weddell Sea Antarctica): ODP Leg 113 holes 689B and 690C: in Barker, P. F., Kennett, J. P., et al., Proceedings of the Ocean Drilling Program, Scientific Results, 113, College Station, TX, p. 489-513.

Huber, B. T., 1992, Paleobiogeography of Campanian-Maastrichtian foraminifera in the southern high latitudes: Palaeogeography, $\mathrm{Pa}-$ laeoclimatology, Palaeoecology, v. 92, p. 325-360.

, and WATKINS, D. K., 1992, Biogeography of CampanianMaastrichtian calcareous plankton in the region of the Southern Ocean: Paleogeographic and paleoclimatic implications. In Kennett, J. P., Warnke, D. A. (eds.), The Antarctic Paleoenvironment: A perspective on global change. Antarctic Research Series, v. 56, p. $31-60$.

JANSEN, H., and Kroon, D., 1987, Maestrichtian foraminifers from Site 605, Deep Sea Drilling Project Leg 93, Northwest Atlantic: in Van Hinte, J. E., Wise, S. W., Jr., et al., Initial Reports DSDP, v. 93, Washington, D. C. (U. S. Government Printing Office), p. $555-575$.

JohnSON, K., 1999, The megaflora of the Hell Creek Formation, southwestern North Dakota: biostratigraphy and paleoecology of the end-Cretaceous terrestrial vegetation. Annual Meetings of the Geological Society of America, Denver, Colorado, abstracts with program, p. 72

Kucera, M., and Malmgren, B. J., 1998, Terminal Cretaceous warming event in the mid-latitude South Atlantic Ocean: evidence from poleward migration of Contusotruncana contusa (planktonic foraminifera) morphotypes: Palaeogeography, Palaeoclimatology, Palaeoecology, v. 138 , p. 1-15.

LANG, T. H., and Wise, S. W., Jr., 1967, Neogene and PaleoceneMaestrichtian calcareous nannofossil stratigraphy, Deep Sea Dril- ling Project Sites 604 and 605, upper continental rise off New Jersey: sedimentation rates, hiatuses, and correlations with seismic stratigraphy: in Van Hinte, J. E., Wise, S. W., Jr., et al., Initial Reports DSDP, v. 93, Washington, D. C. (U. S. Government Printing Office), p. 661-683.

LI, L., and Keller, G., 1998, Abrupt deep-sea warming at the end of the Cretaceous: Geology, v. 26, p. 995-998.

Malmgren, B. A., 1982, Biostratigraphy of planktic Foraminifera from the Maastrichtian white chalk of Sweden: Geologiskaa Föreningens I Stockholm Föhandlingar, v. 103, p. 357-375.

_ 1991 , Biogeographic patterns in terminal Cretaceous planktonic foraminifera from Tethyan and warm Transitional waters. Marine Micropaleontology, v. 18, p. 73-99.

NederbraGt, A. J., 1989, Late Cretaceous biostratigraphy and development of Heterohelicidae (planktic foraminifera): Micropaleontology, v. 37, p. 329-372.

Nyong, E. E., 1985, Campanian to lower Maastrichtian paleobiogeography of the western North Atlantic region: Eclogae Geologische Helvitae, v. 77, p. 469-481.

OLSSON, R. K., and Wise, S. W., 1987, Upper Maestrichtian to middle Eocene stratigraphy of the New Jersey slope and coastal plain: in Van Hinte, J. E., Wise, S. W., Jr., et al., Initial Reports DSDP, v. 93, Washington, D. C. (U. S. Government Printing Office), p. 1343-1366.

-, Miller, K. G., Browning, J. V., Wright, J. D., and CraMER, B. S., 2000, Sequence stratigraphy and sea level change across the Cretaceous-Tertiary boundary on the New Jersey margin: Geological Society of America, Special Paper, (in press).

StotT, L. D., and KenNetT, J. P., 1990, The paleoceanographic and paleoclimatic signature of the Cretaceous/Paleogene boundary in the Antarctic: Stable isotopic results from ODP Leg 113: in Barker, P. F., Kennett, J. P., et al., Proceedings of the Ocean Drilling Program, Scientific Results, 113, College Station, TX, p. 829-848.

Troelen, J. C., 1955, Globotruncana contusa in the white chalk of Denmark. Micropaleontology, v. 1, p. 76-82.

VonHOF, H. B., and SMIT, J., 1997, High-resolution late Maastrichtianearly Danian oceanic $87 \mathrm{Sr} / 86 \mathrm{Sr}$ record: Implications for Cretaceous-Tertiary boundary events: Geology, v. 25, p. 347-350.

WICKER, C. A., 1953, Mikropaläontologische Beobachtungen in der höherer borealen Oberkreide, besonders in Maastricht. Geologische Jahrbuck, v. 68 , p. 1-25.

Wolfe, J. A., and UpChURCH, G. R., Jr., 1987, North American nonmarine climates and vegetation during the Late Cretaceous. Palaeogeography, Palaeoclimatology, Palaeoecology, v. 61, p. 3377.

Received 24 October 2000 Accepted 28 February 2001 